\title{
Hatshepsut and the Apis Race New Quartzite Relief Fragments from Dra' Abu el-Naga
}

\author{
HASSAN AGLAN
}

\begin{abstract}
The reconstruction of a scene sculpted on some quartzite stone fragments discovered recently at Dra' Abu el-Naga and dating from the reign of Hatshepsut is the subject of this paper. The relief resembles the scenes known from the Red Chapel at Karnak and seems to be a part of the wdi sh.t ritual performed on the occasion of the Opet and/or Valley Festivals.
\end{abstract}

Keywords: New Kingdom Egypt, Dra' Abu el-Naga, West Bank, Luxor, Hatshepsut, Opet Festival, Valley Festival

Hassan Aglan, Ministry of Antiquities, Luxor / Institute of Archaeology, Department of Egyptology and Northeast African Archaeology, Humboldt University, Berlin; haglan_77@yahoo.com

The present paper discusses fragments of decorated blocks found during excavations in central Dra' Abu el-Naga, carried out between 2009 and 2011 by the Ministry of State for Antiquities (MSA). The site is situated c. $700 \mathrm{~km}$ south of Cairo, opposite the modern city of Luxor on the West Bank of the Nile. Dra' Abu el-Naga is the modern name of the northern area of the Theban necropolis. Central Dra' Abu el-Naga lies to the north of the causeway of Queen Hatshepsut's temple and just south of the German and Spanish concessions, overlooking the valley where a Temple of Amenhotep I was once erected. The reliefs analysed below were found in area situated just below the hilltop of the middle range of the Dra' Abu el-Naga hills (Fig. 1).

\section{RELIEF FRAGMENTS}

Many blocks were discovered during the removing of debris from the middle part of the valley, which was done in order to reach the bed-rock and the lowermost level of the tombs in central Dra' Abu el-Naga. These fragments were presumably once used as building material for the then contemporary houses. Eleven of them are made of red quartzite and decorated with relief. Some of them are clearly joining to each other, and based on this criteria, the whole collection could be divided into three groups. The fragments are $3-4 \mathrm{~cm}$ thick 


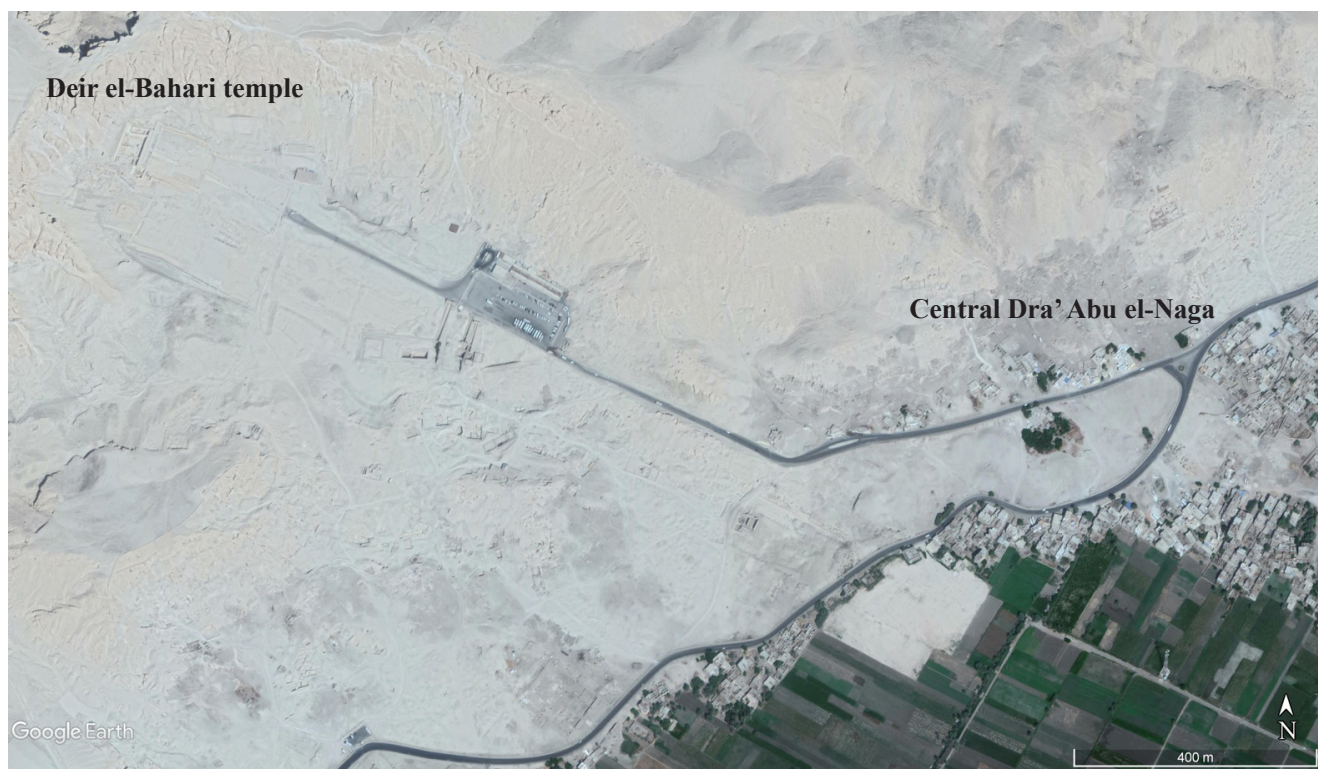

1. Satellite image of Central Dra' Abu el-Naga and Deir el-Bahari temple (Phot. (C GoogleEarth).

and smooth on the back. After arranging them in their reconstructed original position, it became clear that only one piece preserves the lower edge of a block. The decoration is carved in shallow sunken relief and no traces of colour are preserved. The inscription seems to be unfinished (see: Fig. 2b). The style of the relief resembles the best examples from the early Eighteenth Dynasty.

\section{Group 1 (Fig. 2a)}

Dimensions: W. 9cm; H. 6cm; T. 3-4cm

No. of fragments: 1

Description:

Remains of two columns of text divided by a vertical line. On the left side, above the top portions of the signs $h$ and $p$, one stroke and a fragment of another one are visible. In the right column, the signs $m r$ (Gardiner N36). $t($ ), and the upper part of a cartouche can be seen.

\section{Group 2 (Fig. 2b)}

Dimensions: W. $27 \mathrm{~cm}$; H. $18 \mathrm{~cm}$; T. $3-4 \mathrm{~cm}$

No. of fragments: 3

Description:

Preserved is a part of the name of Queen Hatshepsut, followed by n.t h.t ( ) at the bottom of a column. Adjacent to this is a representation of a bull, including the front leg and tip of the nose. To the left of the animal's legs there is a part of a leg of a striding human figure. 

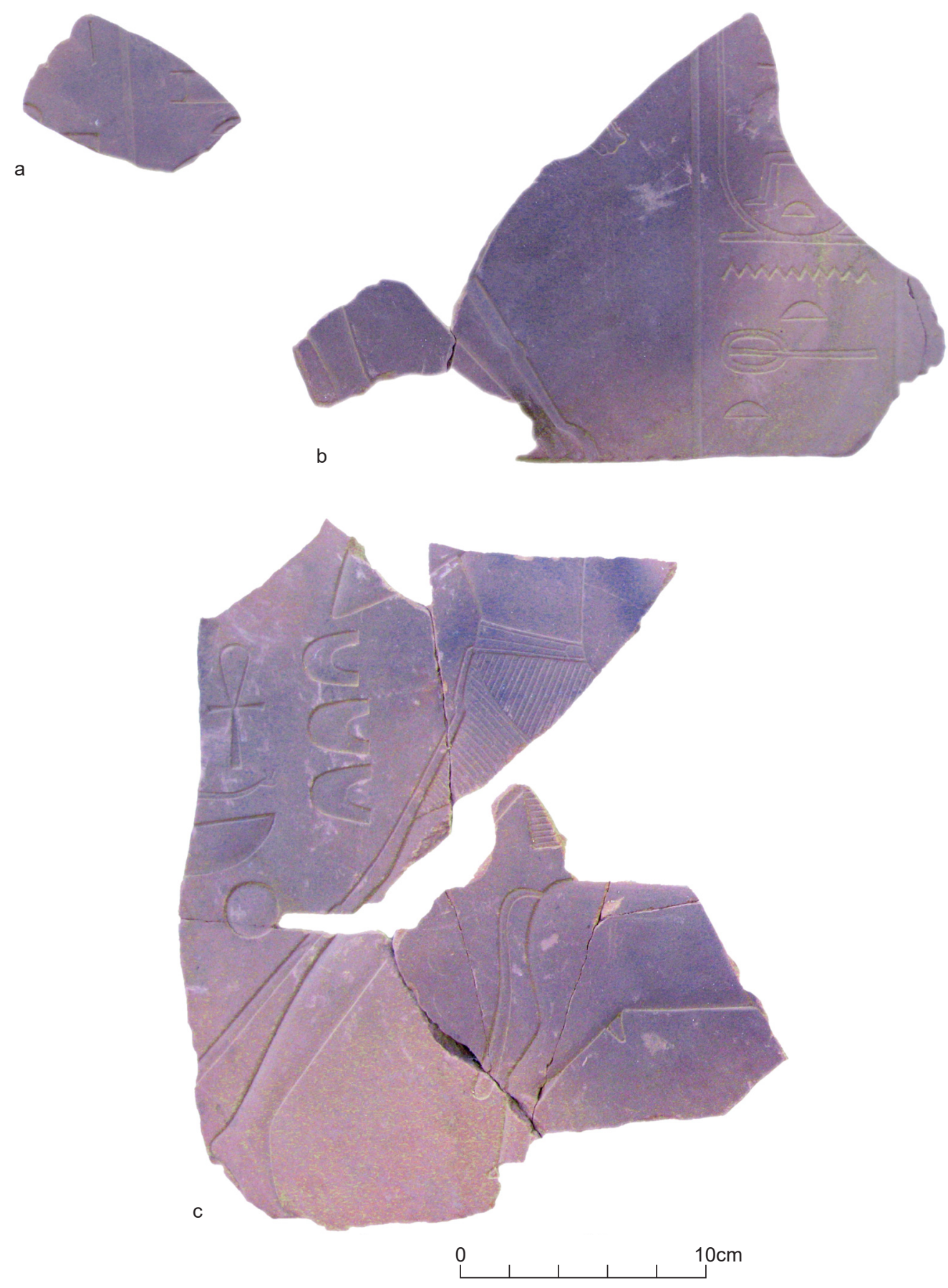

2. Quartzite relief fragments from Dra' Abu el-Naga: a. fragment showing remains of hieroglyphic signs; b. two joined fragments showing the lower part of Hatshepsut's name as well as front leg and tip of the nose of the bull; c. seven joined fragments showing the rear part of the bull, a running figure, and the $\underline{d} n b . w$-signs (Phot. H. Aglan). 


\section{GROUP 3 (Fig. 2c)}

Dimensions: W. $23 \mathrm{~cm}$; H. $29 \mathrm{~cm}$; T. $3-4 \mathrm{~cm}$

No. of fragments: 7

Description: The relief preserves part of a running human wearing a royal kilt and bull's tail. In front of the figure is the rear part of a bull and behind the remains of a text with boundary markers $\underline{d n b . w},{ }^{1}$ an ${ }^{2} h \underline{h} f$ sign, half of a $f \propto$ sign, $n b \smile$ sign, and $R^{e} \odot$ sign.

\section{INTERPRETATION}

The name of Hatshepsut, boundary markers $\underline{d} n b . w$, the striding pose of a human figure, and the running bull, indicate that the fragments once formed a scene depicting the queen running with the bull (Fig. 3). A similar scene was represented twice - on the south and north walls - of the so-called Red Chapel, now standing in the Open Air Museum in the Karnak temple. There, the queen was depicted as the ruler of Lower Egypt, wearing the Red Crown, ${ }^{2}$ and as that of Upper Egypt, wearing the White Crown. ${ }^{3}$

Based on the parallel from the Red Chapel, the signs on the fragments from Dra' Abu el-Naga can be reconstructed.

Column to the right of the scene:

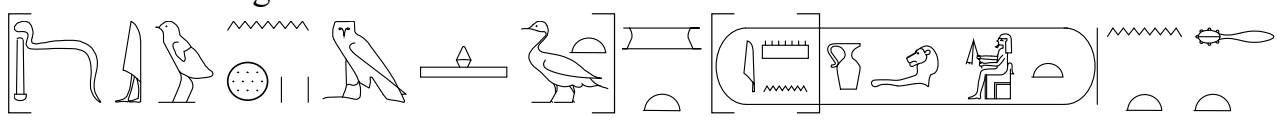

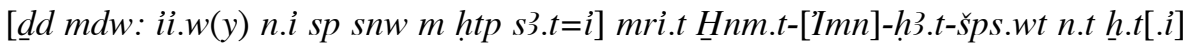

[Words spoken: Come to me, come to me in peace my] beloved [daughter] Hatshepsut of [my] body.

The text in front of the royal figure:

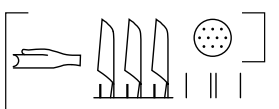

[wdi sh.t sp] 4

[Giving a field,] four [times]

${ }^{1}$ dnb.w-markers are often represented in the reliefs of Hatshepsut (e.g. Naville 1895: Pls XIX, XXII; 1901: Pl. XCIII; 1908: Pl. CLVII; Burgos, Larché 2006: 133, 137, 151, 153, 164, 181, etc.), although in this case the present author would suggest that they are just a symbol of the number 30 and that they allude to the Heb-sedfestival. Some scholars speculate that Hatshepsut may have celebrated her first Sed-jubilee to mark the passing of thirty years from the death of her father, Thutmose I, from whom she derived all of her legitimacy to rule Egypt. See, for example: Beckerath 1997: 201.

2 Blocks 102 and 128: Lacau, Chevrier 1977: 195 (Part I), Pl. 9 (Part II); Burgos, Larché 2006: 110.

${ }^{3}$ Blocks 102 and 128: Lacau, Chevrier 1977: 195 (Part I), Pl. 9 (Part II); Burgos, Larché 2006: 63, 110 . 


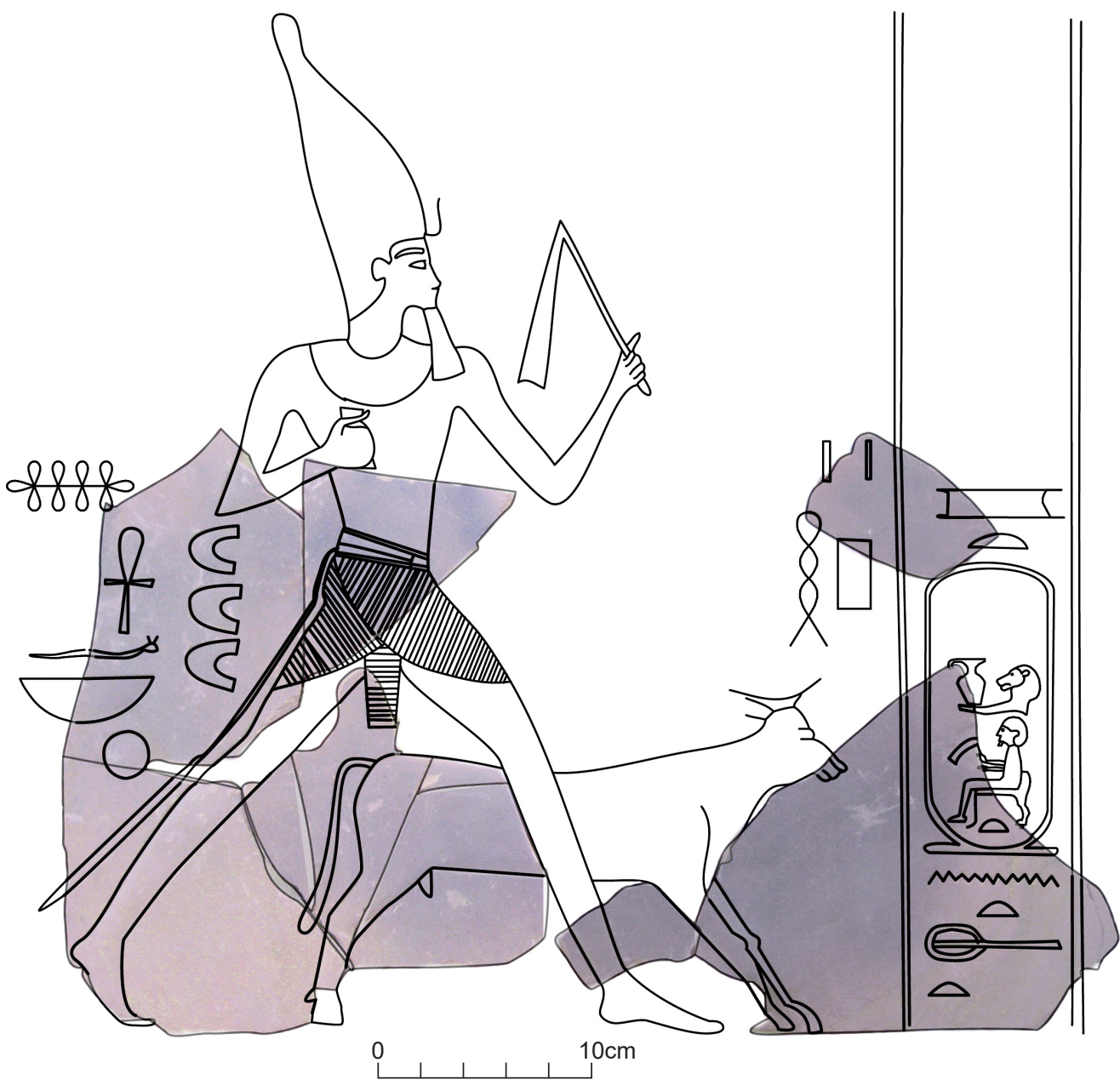

3. Theoretical reconstruction of the scene sculpted on the quartzite fragments (Drawing and digitising: H. Aglan).

Above the bull:

$\square 8\left[\sum_{\mathbb{A}} \hat{\sim} \boldsymbol{B}\right]^{4}$

$p h[r r H p]$

The racing of [Apis].

The reconstruction indicates that Hatshepsut was accompanied by the Apis bull. ${ }^{5}$

\footnotetext{
${ }^{4} \mathrm{~Wb}$ I, 541, 12.

${ }^{5}$ Lacau, Chevrier 1977: 428.
} 
The signs behind the figure of Hatshepsut are part of a protection formula:

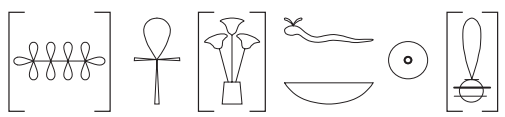

[s3] ' $n h$ [h3].f $n b[\mathrm{mi}] R^{\top}$

All [protection] and all life [to] him $^{6}$ [like] Re.

\section{CONCLUSIONS}

Based on parallels from the Red Chapel, it is clear that these fragments are part of a larger scene that represents Hatshepsut performing rituals of wdi sh.t on the occasion of the Opet and/or Valley Festivals, i.e. in the context where she was depicted once as a ruler of Upper Egypt and once as a ruler of Lower Egypt. Hatshepsut probably holds in one hand the nekhakha-whip and in the other hand the mekes-container. It can be proposed that on the discussed fragments she was depicted as the ruler of Upper Egypt (Fig. 4). ${ }^{7}$

The text under Hatshepsut's name, n.t h.t, indicating that the whole scene was not completed, as mentioned above.

The fact that at the site no other quartzite blocks were found that could match the above discussed fragments makes it difficult to determine the exact original location and function of these reliefs. However, it is possible to contextualise them. The scene is exactly of the same scale as the rituals of wdi sh.t scene in the Red Chapel, and both reliefs are made of the same material, so one could posit that the blocks found at Dra' Abu el-Naga were brought from Karnak. However, the thickness of the analysed fragments, which is about 3 to $4 \mathrm{~cm}$, clearly differs from that of the blocks in the Red Chapel, which are either $70-80 \mathrm{~cm}$ thick or about half of these dimensions. It cannot be ruled out that the fragments from Dra' Abu el-Naga once had the same thickness and that they have been hacked and smoothed. ${ }^{8}$ However, a more likely explanation is that the $3-4 \mathrm{~cm}$ represents the original thickness of the reliefs and that these were used as casing slabs of a wall, such as is attested for the Mentuhotep II temple at Deir el-Bahari and Pylons VII and VIII at Karnak. ${ }^{9}$ Also Hatshepsut used this technique in her tomb with respect to the slabs on which Amduat scenes are represented. ${ }^{10}$ Such slabs could face both stone walls as well as those built of soft material (a mud brick wall, a wall cut in the bedrock etc.). In the case

\footnotetext{
${ }^{6}$ Suffix $f$ for masculine was used instead of.$s$ suffix for feminine: Lacau, Chevrier 1977: 196.

7 This proposal is based on the wdi sh.t scene of Hatshepsut in the Red Chapel, where she is wearing the White Crown and in front of her there is an inscription ' $d d m d w$ ỉ.w $(y)$ n.i $m$ htp s3t[.i] mri.t $<\underline{H}$ Hmt-Imn-ḩ3t-

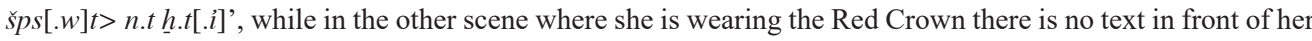
but instead the barque of Amun-Re (Lacau, Chevrier 1977: 195).

${ }^{8}$ The fragments are now stored in the MSA magazine, so it was not possible to re-examine the reliefs and check this point.

9 Arnold 1991: 148.

${ }^{10}$ Mauric-Barberio 2001: 315-350.
} 


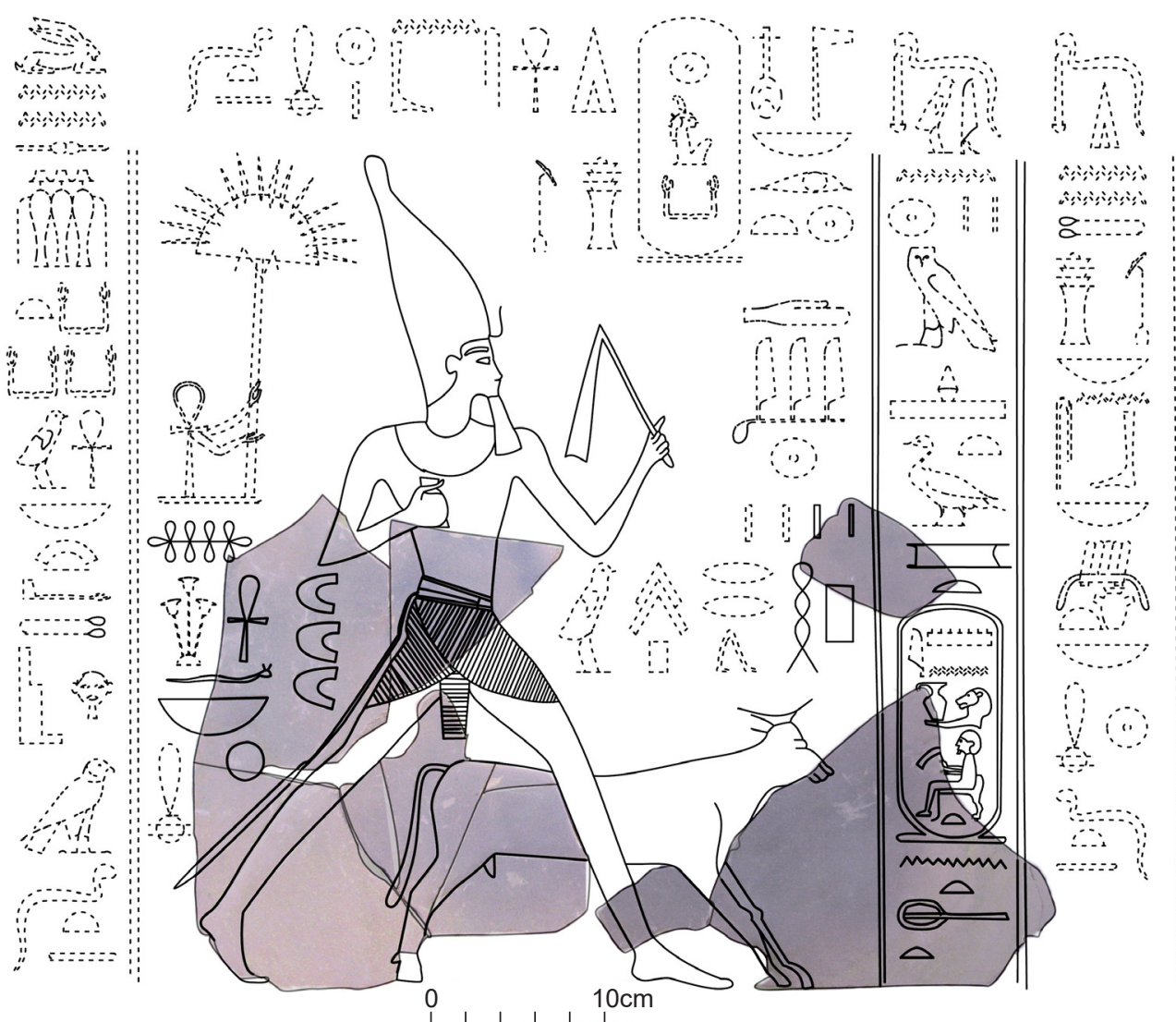

4. Reconstruction of the Runnig of Apis scene, based on representation from the Red Chapel (Drawing and digitising: H. Aglan).

of the VIII Pylon in Karnak, there were limestone blocks, and not a very rare quartzite one. Moreover, they were inscribed with a text, and placed at the foot of the pylon, while those from Dra' Abu el-Naga, must have been placed much higher on the wall, since they were decorated with a scene.

The presence of this very material should be noted and stressed because during Hatshepsut's reign in the royal constructions it appears very rarely, i.e. in the the Red Chapel, in two sarcophagi of the queen ${ }^{11}$ and some minor objects like name stones. ${ }^{12}$

The author would like to suggest that the newly discovered fragments once were part of a barque shrine of Hatshepsut on the West Bank, related to the processional way leading to Deir el-Bahari (Fig. 5). Jean-Baptiste Prosper Jollois and Édouard de Villiers du Terrage, who participated in the French expedition of 1798, made a plan that is the earliest

\footnotetext{
11 Iwaszczuk 2016: 319, 325-326.

12 Iwaszczuk 2016: 21-22.
} 


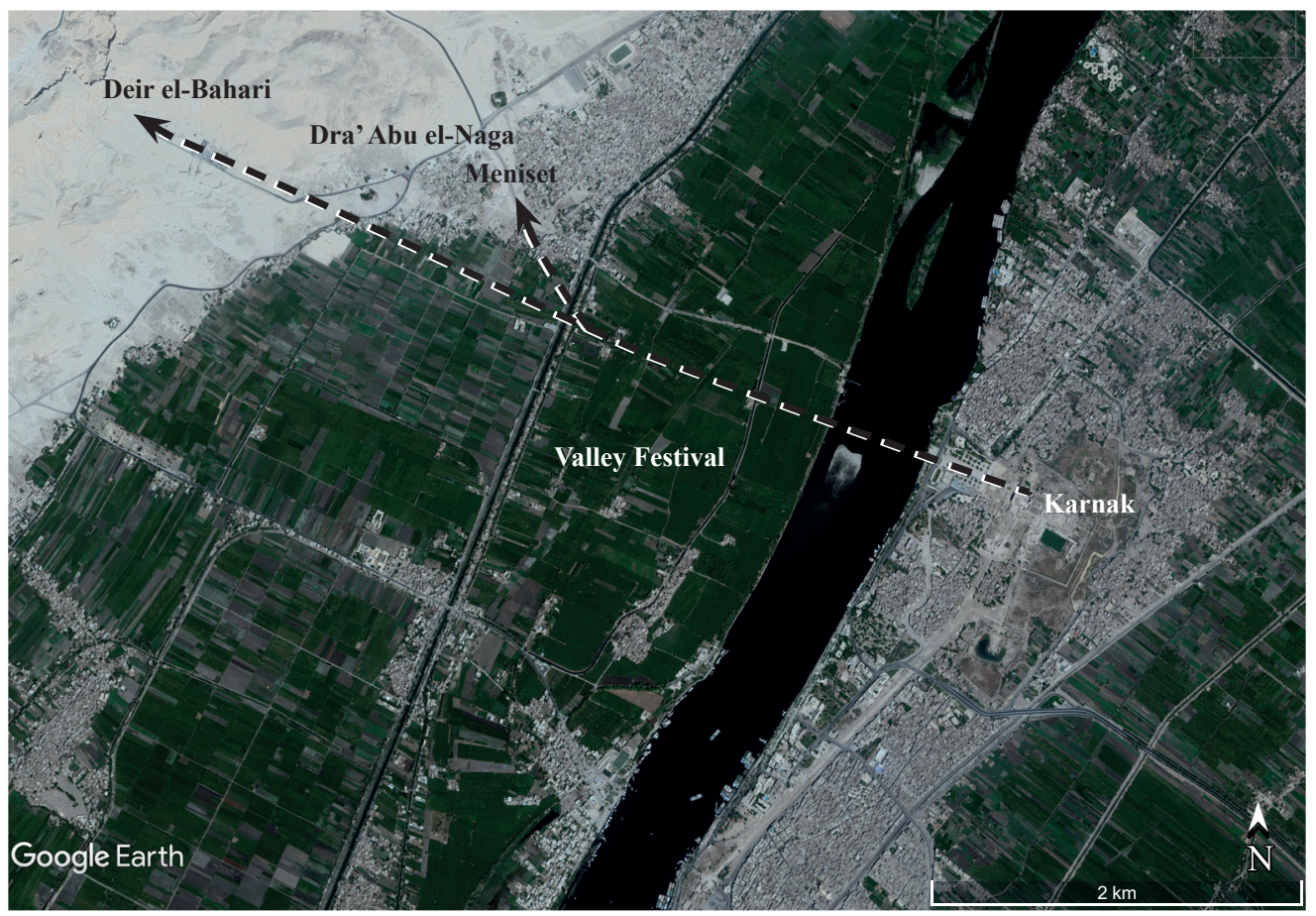

5. Satellite image illustrating the suggested procession way of Valley Festival between Karnak and Deir el-Bahari in the reign of Hatshepsut; the polygon shape in Dra' Abu el-Naga indicates the location of discovered fragments (Phot. (C) GoogleEarth).

detailed documentation of the processional way to Deir el-Bahari. ${ }^{13}$ The plan shows that the processional way was lined by sphinx bases, and that there is a gap in the half of its length, where a limestone barque shrine was placed,$^{14}$ of which remains are still visible in situ. There is of course a possibility this barque shrine was not connected with Deir el-Bahari, although the Temple of Hatshepsut is the nearest attested construction of the queen, or at least its easternmost part, i.e. the Valley Temple which, however, according to the explorers, was never finished. ${ }^{15}$

Nonetheless, if one assumes that the discussed reliefs from Dra' Abu el-Naga were originally part of a barque shrine of Hatshepsut on the West Bank, they had to belong to another barque shrine, since they were made of quartzite, and not limestone. Perhaps it was located on one of the terraces at Deir el-Bahari. It could have been in the lower terrace.

13 Naville 1894: 1, n. 1.

14 Arnold 2008: 22, Fig. 8. A possible reconstruction of what the road might have looked like under Hatshepsut was proposed by Felix Arnold, who suggests that the causeway leading to her mortuary temple at Deir el-Bahari also served as a road for processions. The barque shrine divided the processional way into an upper and a lower section. In the upper section, which is $525 \mathrm{~m}$ long, there are two rows of sphinxes along the way grouped in two parallel tracks. Between the sphinxes were small trees. The $37 \mathrm{~m}$ wide road was bordered on both sides by high walls. The width of the passage itself is $5.5 \mathrm{~m}$, so there remained plenty of room for spectators.

15 Carter 1912: 38-39; Lythgoe, Lansing, Davies 1917: 10. 
The only known remains from the terrace are the T-shaped water tanks for papyrus and circular plantings beds for two trees, therefore there was plenty of space left. ${ }^{16}$ The barque shrine could serve there as a stop for priests before they climb up on the stairs.

Since the scene depicted on the new blocks is unfinished and the name of the queen is not chiseled out, this indicates that the building did not survive the reign of Hatshepsut. On the other hand this can also suggest that the barque shrine was planned to be added in a later phase of construction of the temple itself, and that the work was stopped because of the queen's death, and blocks from the barque were destroyed by her successors. ${ }^{17}$

We may conclude that the new fragments from Dra' Abu el-Naga are likely to attest a presence of another barque shrine of Hatshepsut on the West Bank of the Nile. Significantly different in building technique from the Red Chapel in Karnak, this new quartzite shrine had a remarkably similar design, including one of the festival scenes. It would require further fragments to establish any further arguments supporting links to the scenes found on the Red Chapel.

\section{Acknowledgments}

The author would like to express his deepest gratitude to Julia Budka for helpful discussion and suggestions concerning the presented above material.

\section{References}

Arnold, Di. 1979: The Temple of Mentuhotep at Deir el-Bahari, Mainz a/Rhein Arnold, Di. 1980: Deir el-Bahari III, [in:] LÄ I, 1017-1023

Arnold, Di. 1991: Building in Egypt: Pharaonic Stone Masonry, New York

Arnold, F. 2008: Pharaonische Prozessionsstrassen, Mittel der Machtdarstellung unter Königin Hatschepsut, [in:] Schwandner, E.-L., Rheidt, K. (Eds), Macht der Architektur - Architektur der Macht, Bauforschungskolloquium in Berlin vom 30. Oktober bis 2. November 2002 veranstaltet vom Architektur-Referat des DAI, Mainz a/Rhein, 13-23

Beckerath, J. von 1997: Chronologie des pharaonischen Ägypten. Die Zeitbestimmung der ägyptischen Geschichte von der Vorzeit bis 332 v. Chr., Mainz a/Rhein

Burgos, F., Larché, F. 2006: La chapelle Rouge : le sanctuaire de barque d'Hatshepsout. 1. Fac-similés et photographies des scènes, Paris

Carter, H. 1912: The 'Valley'-Temple of Queen Hatshepsût, [in:] Earl of Carnarvon, Carter, H., Five Years' Explorations at Thebes. A Record of Work Done 1907-1911, London, 38-41

Iwaszczuk, J. 2016: Sacred Landscape of Thebes during the Reign of Hatshepsut, Royal Construction Projects, Volume 2. Topographical Bibliography of the West Bank,

\footnotetext{
16 Winlock 1942: 90, Pl. 46; Arnold 1979: P1. 6; 1980: 1014, 1019 [6], Fig. 1 [11].

17 However, it is also possible that the blocks broke during the work and were therefore thrown away.
} 
Ed. Laskowska-Kusztal, E., Travaux de l'Institut des Cultures Méditerranéennes et Orientales de l'Académie Polonaise des Sciences III, Varsovie

Lacau, P., Chevrier, H. 1977: Une chapelle d'Hatshepsout à Karnak I, Le Caire

Lythgoe, A.M., Lansing, A., Davies, N. de G. 1917: The Egyptian Expedition 1915-16, BMMA 12/5, 3-31

Mauric-Barberio, F. 2001: Le premier exemplaire du Livre de l'Amdouat, BIFAO 101, 315-350

Naville, E. 1894: The Temple of Deir el Bahari: Its Plan, Its Founders, and Its First Explorers. Introductory Memoir, MEEF 12, London

Naville, E. 1895: The Temple of Deir el Bahari. Part I. The North-Western End of the Upper Platform, MEEF 13, London

Naville, E. 1901: The Temple of Deir el Bahari. Part IV. The Shrine of Hathor and the Southern Hall of Offerings, MEEF 19, London

Naville, E. 1908: The Temple of Deir el Bahari. Part VI. The Lower Terrace, Additions and Plans, MEEF 29, London

Winlock, H.E. 1942: Excavations at Deir el Bahri, 1911-1931, New York 


\section{ÉTUDES et TRAVAUX XXXI / 2018}

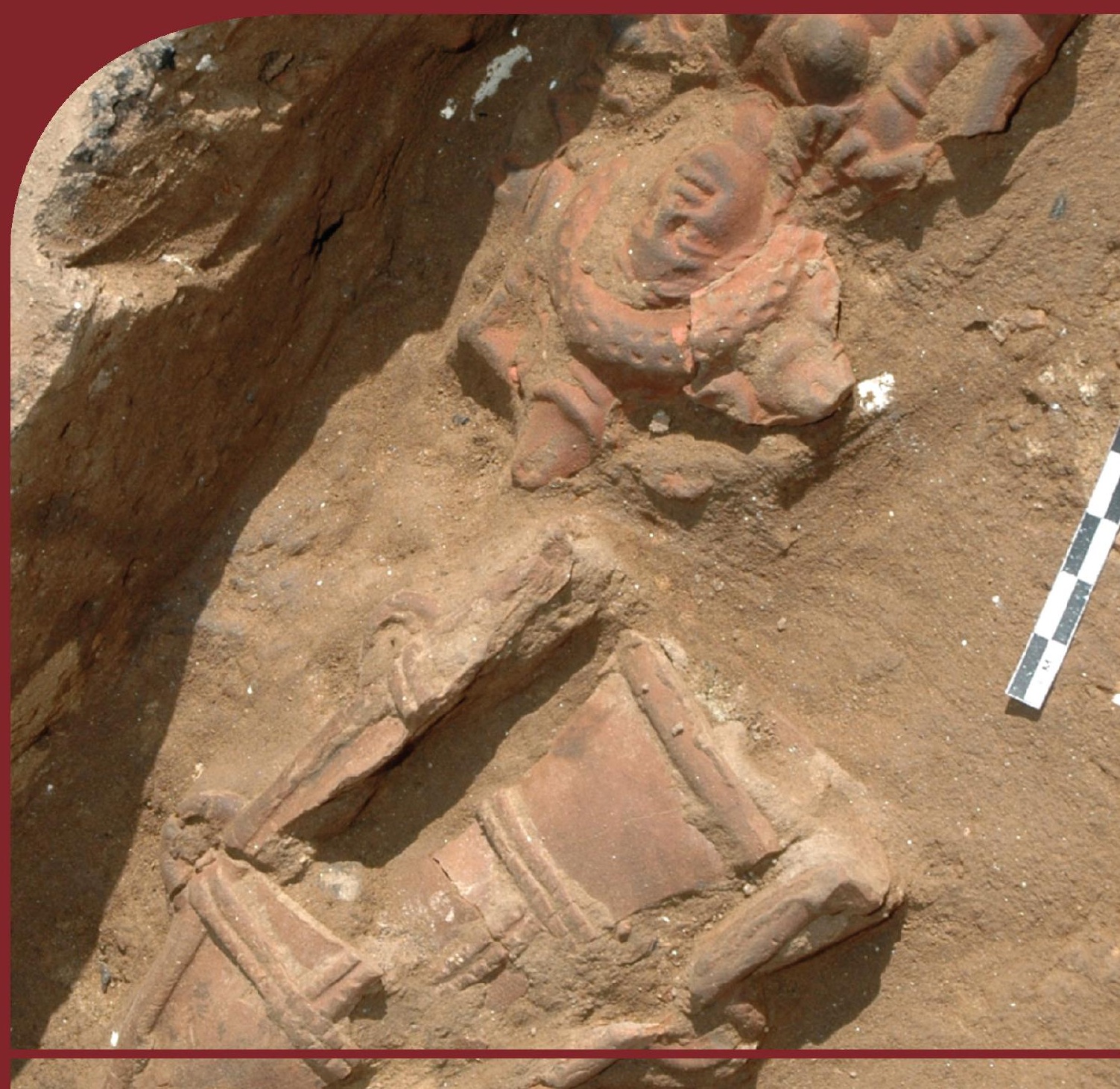

Institut des Cultures iyréditerranéennes et Oilentales FORIKSiO - de PAcadémie Polonaise des Sciences DS PA 


\section{COMITÉ DE RÉDACTION SCIENTIFIQUE}

Maciej Makowski - rédacteur en chef

Jadwiga Iwaszczuk - rédacteur

Mariusz Drzewiecki - sécretaire de la rédaction

Karol Myśliwiec - rédacteur thématique du volume

CONSEIL SCIENTIFIQUE DU JOURNAL

M. Kobusiewicz (IAE PAS, Warszawa), E. Laskowska-Kusztal (IMOC PAS, Warszawa)

D. Michaelides (University of Cyprus, Nicosia)

J.Ch. Moretti (IRAA-MOM, Université de Lyon 2/CNRS)

D. Raue (Ägyptisches Museum der Universität Leipzig), P. Reynolds (ICREA, España)

D. Welsby (British Museum, London)

\section{COMITÉ SCIENTIFIQUE DE LECTURE}

H.D. Baker (University of Toronto), P. Ballet (ArScAn-ESPRI, Université Paris Nanterre),

N. Beaux Grimal (IFAO, Cair/Collège de France, Paris), A. Dodson (University of Bristol),

L. Gabolde (CNRS), C. Gobeil (Egypt Exploration Society, London),

J. Holaubek (Institut für Ägyptologie, Wien), S. Ikram (American University in Cairo),

K. Innemée (Universiteit Leiden), Ch. Leitz (Universität Tübingen),

A. Loprieno-Gnirs (Universität Basel), Ch.E. Loeben (Museen für Kulturgeschichte, Hannover),

S. Ortisi (Universität München), A. Peignard-Giros (HiSoMA-MOM, Université de Lyon 2/CNRS),

E. Rova (Università Ca' Foscari Venezia), A. Sasson (San Diego Natural History Museum),

G. Schreiber (Eötvös Loránd University, Budapest), E. Teeter (University of Chicago),

Y. Tristant (Macquarie University, Sydney), V. Vaelske (independent researcher),

V.W.J. van Gerven Oei (independent researcher), H. Vymazalová (Charles University, Prague),

K. Winther-Jacobsen (Danish Institute at Athens),

J.A. Ostrowski, E. Papuci-Władyka, J. Śliwa (IA JU, Kraków),

R. Czerner (WUST, Wrocław), A. Ćwiek (IA AMU, Poznań),

K. Domżalski (IAE PAS, Warszawa), M. Pinker (FOS UW, Warszawa),

Ł. Niesiołowski-Spanò (IH UW, Warszawa), M. Gawlikowski (PCMA UW, Warszawa), K.O. Kuraszkiewicz (DE FOS UW, Warszawa), M. Barwik, P. Dyczek, W. Godlewski,

S. Rzepka, J. Żelazowski, A. Niwiński (IA UW, Warszawa)

\section{RÉDACTION TECHNIQUE}

Maciej Makowski, Jadwiga Iwaszczuk

CORRECTION LINGUISTIQUE

Jo Harper 
ÉTUDES et TRAVAUX

XXXI 
INSTYTUT KULTUR ŚRÓDZIEMNOMORSKICH I ORIENTALNYCH POLSKIEJ AKADEMII NAUK

\title{
STUDIA i PRACE
}

XXXI

\author{
gO IKŚiO \\ ESA PAN \\ WARSZAWA \\ 2018
}


INSTITUT DES CULTURES MÉDITERRANÉENNES ET ORIENTALES DE L'ACADÉMIE POLONAISE DES SCIENCES

\section{ÉTUDES et TRAVAUX}

XXXI

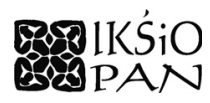

VARSOVIE

2018 
Publication scientifique financée dans le cadre du programme du Ministre de la Science et de l'Éducation Supérieure « Programme National de Développement de l'Humanistique » pour les années 2016-2021 (projet $n^{\circ} 3 \mathrm{bH} 15009983$ )

\title{
Harodowy PROGRAM ROZWOJU HUMANISTYKI
}

\author{
Copyright $($ ) \\ Instytut Kultur Śródziemnomorskich i Orientalnych PAN \\ et les Auteurs \\ Warszawa 2018
}

ISSN 2084-6762

(avant $2011: 0079-3566$ )

e-ISSN 2449-9579

Version première en papier, imprimée en Pologne - 150 copies

Version électronique accessible sur http://www.etudesettravaux.iksiopan.pl

Édition: Polskie Towarzystwo Historyczne et Wydawnictwo Neriton, Warszawa

Conception générale de couverture : J. Iwaszczuk Photo de couverture : P. Moser (C) Schweizerisches Institut für Ägyptische Bauforschung und Altertumskunde in Kairo

(terre cuites d'Aswan/Syene) 


\section{Table des matières}

KAROL MYŚLIWIEC

$(E T=E t u d T r a v / 50) \times 30$

HASSAN Aglan

Hatshepsut and the Apis Race: New Quartzite Relief Fragments

from Dra' Abu el-Naga

Amgad Joseph

Divine Wrath in Ancient Egypt

Amgad Joseph

Pain Infliction, Inflictors and Healers in Egyptian Religious, Magical

and Literary Perceptions

MirosŁaW BarwiK

New Dipinti in the Birth Portico of the Hatshepsut Temple at Deir el-Bahari

KrzyszTOF BorysŁaWsKi, ANNA NiwiŃSKA, ANDRZEJ NiwiŃSKI,

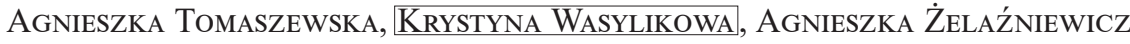

A Bulb of Narcissus on the Egyptian Mummy from University

of Wrocław Collection

LINDA CHAPON

Some Reliefs Representing the King in the Heb Sed Robe Discovered in the Henket-Ankh

Philippe Guillaume

Debunking the Latest Scenario on the Rise of the Pork Taboo

Mariola Hepa

A Clay Gladius Scabbard from Area 13c in the Ancient Roman Town of Syene

Emanuele E. Intagliata

Pinpointing Unrest at Palmyra in Early Islamic Period. The Evidence from Coin Hoards and Written Sources 
KATARZYNA KAPIEC

The Sacred Scents: Examining the Connection Between the ' $n t j w$ and $s f \underline{t}$ in the Context of the Early Eighteenth Dynasty Temples

DOMINIKA MAJCHRZAK

Remarks on the Iconographic Motif of the Birdman in Mesopotamian Glyptic Art of the Third Millennium BC

KAROLINA PAWLIK

Stone Artefacts from Late Roman Occupation Phases in Nea Paphos

ABRÉVIATIONS 
THE VOLUME IS PUBLISHED TO CELEBRATE

THE $50^{\text {TH }}$ ANNIVERSARY

OF THE

ÉTUDES ET TRAVAUX

ESTABLISHED IN 1966 